\title{
VII. CLASSICAL THEORY OF PAIRS
}

